\title{
Landscaping on or near Septic Drain Fields ${ }^{1}$
}

\author{
Whitney C. Elmore, William Lester, James Moll, Andrea Albertin, and Mary Lusk ${ }^{2}$
}

\section{Introduction and Purpose}

Septic systems are designed to move wastewater away from a home or building, allowing the solids to separate from liquids. While the solids are decomposed by bacteria in a holding tank (Figure 1) outside of the home, the liquids, or effluent water, flow out of the tank through a series of perforated drain pipes, allowing the percolation of wastewater out and away from the home into an area known as the drain field (also called a leach field). The liquid is then filtered by sediment and rock layers while microbes continue decomposition of the effluent before it filters down into groundwater. Proper construction and maintenance of the drain field is essential in ensuring the process works correctly to limit the harmful bacteria and pollutants subsequently entering the groundwater. Environmental pollutants, such as nitrogen and phosphorous, serve as nutrient sources for algal blooms along coastal waters and as pollutants in lakes, rivers, streams, and springs. Even the most efficient conventional septic system removes only approximately $30 \%$ of the nitrogen waste and about $60 \%$ of the phosphorus that enters it, leaving the rest to infiltrate to groundwater resources (Lusk et al. 2016).

Septic systems are common throughout most rural areas, and their care and maintenance are essential to the health of people, wildlife, livestock, agricultural commodities, and water resources. One way to ensure optimal performance of your septic system is to landscape appropriately near the drain field. The purpose of this publication is to provide landscape management guidance for septic system drain fields. Information presented here will be useful for homeowners, landscape management professionals, and Extension agents who work in horticulture, natural resources, agriculture, and family services.

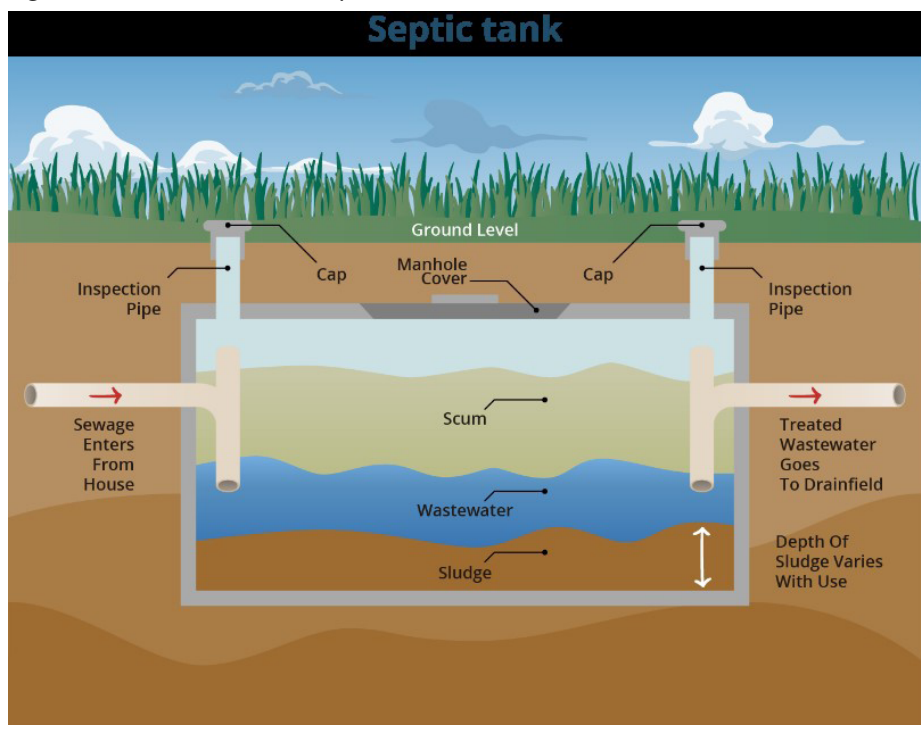

Figure 1. A conventional septic tank.

Credits: UF/IFAS GCREC Urban Soil and Water Quality Lab.

\section{Managing Water around the Drain Field}

The drain field normally runs under other areas of residential land deemed desirable for landscaping, so care must be taken to ensure the plants on and around the drain field do not penetrate or interfere with the function of the drain

1. This document is SL474, one of a series of the Department of Soil and Water Sciences, UF/IFAS Extension. Original publication date September 2020. Visit the EDIS website at https://edis.ifas.ufl.edu for the currently supported version of this publication.

2. Whitney C. Elmore, county Extension director and Extension agent III, UF/IFAS Extension Pasco County; William Lester, Extension agent II, UF/IFAS Extension Hernando County; James Moll, coordinator, education/training, UF/IFAS Extension Pasco County; Andrea Albertin, regional specialized agent—northwest; and Mary Lusk, assistant professor, Department of Soil and Water Sciences, UF/IFAS Gulf Coast Research and Education Center, Wimauma, FL 33598.

The Institute of Food and Agricultural Sciences (IFAS) is an Equal Opportunity Institution authorized to provide research, educational information and other services

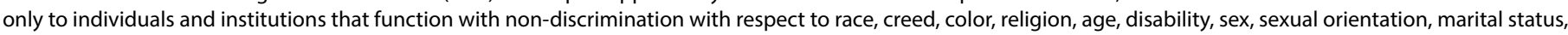

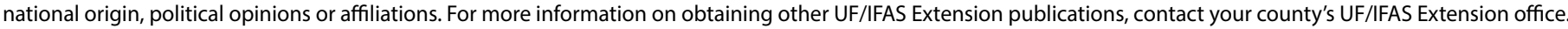
U.S. Department of Agriculture, UF/IFAS Extension Service, University of Florida, IFAS, Florida A \& M University Cooperative Extension Program, and Boards of County Commissioners Cooperating. Nick T. Place, dean for UF/IFAS Extension. 
field. Furthermore, oxygen is required by the beneficial bacteria that break down harmful waste products in the drain field, so overcompaction or excessive traffic across the drain field must be avoided (Dickert 2010). Runoff from roofs and gutters should be directed away from the drain field, and irrigation systems should not be aimed at or installed in these areas. Sprinkler heads should be directed so that irrigation water stays at least $10 \mathrm{ft}$ away from the drain field. The more water moving across and down through the drain field, the less opportunity there is for pollutants to be filtered before moving into the groundwater below. Time is a necessary component in effective waste filtering of septic systems. Having a detailed property survey showing the drain field location is critical in helping avoid costly damage to the system and the environment when landscaping, installing irrigation, or doing any type of construction around a home or business with a septic system.

\section{Plants for the Drain Field}

Landscaping the drain field is possible and can help prevent soil erosion. The right plants can help regulate some of the gas exchange required for the septic system to work properly as well. However, only shallow-rooted plants are acceptable on or near the drain field. Plants with large, deep roots, tap roots, or plants that have a woody root system structure cannot only prevent the system from functioning properly, but they can damage the system by growing into the pipes, requiring expensive repairs and even backups of wastewater into and around the home (Dickert 2010). Avoid salt-sensitive plants, or have your drain field soil tested for salt levels before using plants with low salt tolerance. The UF/IFAS Extension Soil Testing Laboratory can test soil salinity (ESTL; https://soilslab.ifas.ufl.edu).

Turfgrasses are the most common and easiest to establish and maintain around septic systems. They have relatively shallow and fibrous roots. In comparison to other types of plants, turfgrasses tend to be less expensive and can require lower maintenance as long as the right type of grass is chosen for the location. Turfgrass growing over the drainfield should not be fertilized. Wildflower mixes (those native to the state, suited for the site conditions, and produced within the same climate) used in conjunction with turfgrasses can provide a beautiful area with little to no maintenance, but stay away from planting any sort of large or tall grass species, because these can have expansive root systems. Bamboo species, pampas grass, and similar should not be planted due to their deep, expansive roots. St. Augustinegrass (Figure 2), bahia, zoysia and bermudagrass are all acceptable over drain fields.

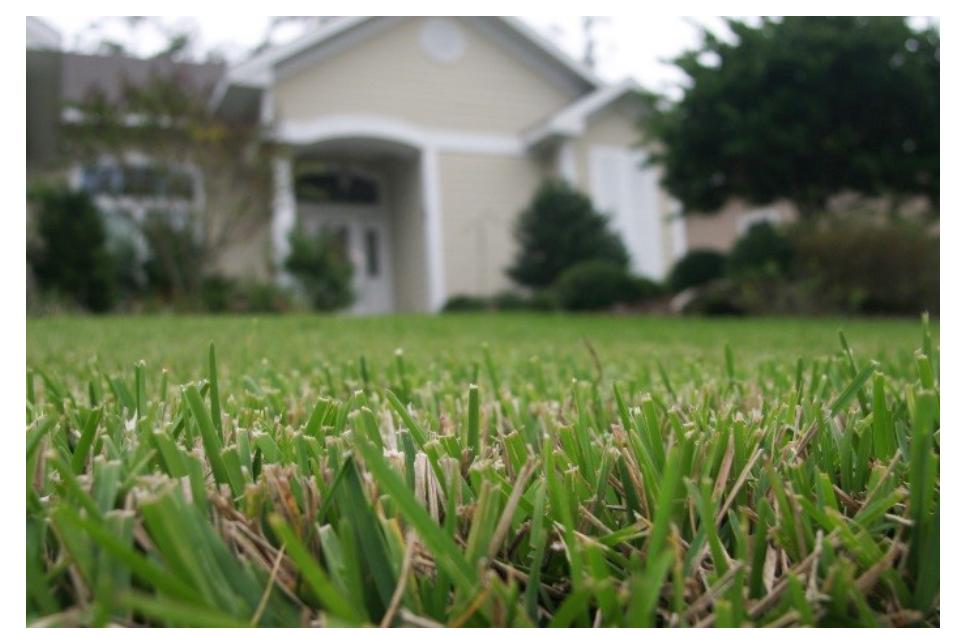

Figure 2. St. Augustinegrass Lawn.

Credits: UF/IFAS

Edible crops and vegetable gardens should not be planted on or near the septic tank or drain field because there is a chance that dangerous bacteria or pollutants can potentially enter into the food chain. Plus, the added fertilizer and irrigation in gardens will only add to the nutrient load making its way through the drain field. Furthermore, some root vegetables could damage the system below or attract large animals, such as deer or wild hogs, whose feeding activity can lead to more compaction or even bare soil over the drain field.

If turf cannot be planted or is not desirable, herbaceous plants, such as fountain grass, iris, Agapanthus, milkweed (Figure 3), aster, plumbago, and pink Muhly grass, are great options to plant on or around the drain field. Planting the right plant in the right place is critical to not only the function of a septic system but also the longevity of the plant itself. Do not plant sun-loving plants in shady spots and vice versa. A wet drain field can be a sign of septic system failure, so plants suffering symptoms caused by having too much water may signal that a septic system inspection is due.

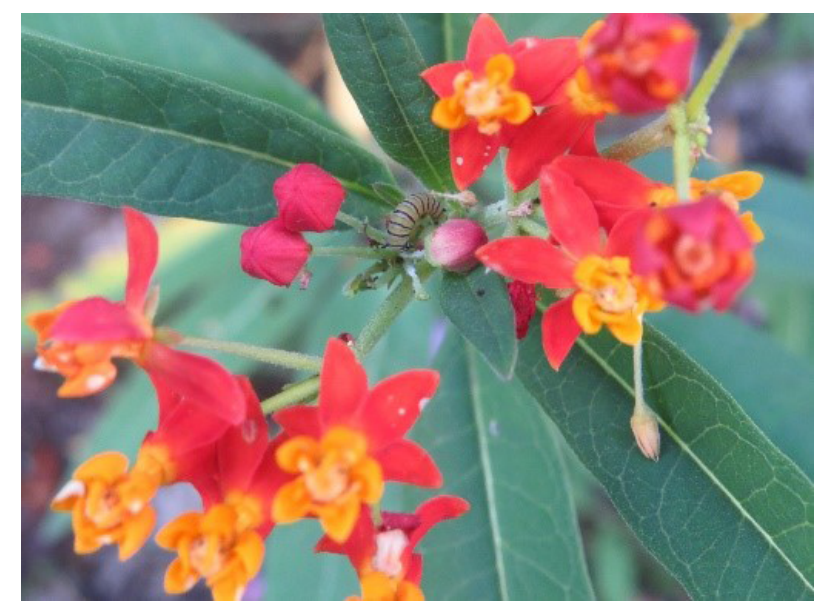

Figure 3. Milkweed.

Credits: Mary Lusk, UF/IFAS 


\section{Additional Landscape Considerations}

Because the drain field pipes can be just a few inches beneath the soil and $18 "-36$ " wide, with pipes 8 to 10 feet apart, avoid the following when landscaping on or near a septic drain field:

- Adding more soil to the area

- Tilling the area for planting

- Mulching any of the drain field area (plastic, bark, rock, or any type of mulch)

- Plants that require supplemental fertilizer or irrigation

- Using landscape fabric

- Digging with shovels or tools below 6" in depth

- Planting trees or shrubs of any kind on or near the drain field

Tree roots can easily grow 2-3 times the width of the tree's canopy, so planting a large tree that might be 30 feet in diameter within 20 feet of a drain field is a receipe for septic system failure (Dickert 2010). Careful examination of the drain field blueprints can help prevent costly mistakes.

\section{Conclusions}

Remember to avoid any sort of modifications aboveground that might impact the drain field below. Plants with shallow roots can help by preventing erosion and even filter some pollutants, but plants with deep, expansive root systems or those requiring a lot of maintenance or division over time can cause septic failure. Drain field plants may remove some pollutants from the septic system area, but most pollutant removal is carried out by the soil through processes such as filtering and absorption to soil particles (Toor et al. 2011). Because septic tank effluent enters the drain field soil at a depth below the rooting zone of most landscape plants, plant uptake and removal of pollutants is minimal (Lusk et al. 2011). Avoid compacting the soil above a drain field by not driving across the area or using it for heavy activity, and do not risk severe septic system damage by digging into the drain field.

\section{References}

Dickert, G. M. 2010. Landscaping over Septic Drain Fields. HGIC 1726. Greenville, SC: Clemson Cooperative Extension.

Lusk, M., et al. 2017. "A Review of the Fate and Transport of Nitrogen, Phosphorus, Pathogens, and Trace Organic Chemicals in Septic Systems." Critical Reviews in Environmental Science and Technology 47 (7): 455-541.

Toor, G., M. Lusk, and T. Obreza. 2011. Onsite Sewage Treatment and Disposal Systems: Nitrogen. SL348.

Gainesville: University of Florida Institute of Food and Agricultural Sciences. https://edis.ifas.ufl.edu/ss550 